\title{
IMPROVING THE KNOWLEDGE OF ECOLOGICAL CONTENT IN PUPILS IN INTERDISCIPLINE FOR TEACHING BIOLOGY
}

\author{
Hushbak Babanazarovich Narbutaev \\ Doctor Of Pedagogical Sciences, Termez State University Uzbekistan
}

\section{ABSTRACT}

This article talks about the problems of introducing knowledge of the interdisciplinary content of connections in the educational process, about the importance of their development, about improving the ecological content of pupils' knowledge in interdisciplinary biology teaching, about creating problematic situations, about introducing communication in society into the curricula and programs of general education schools, the introduction of environmental tasks into interdisciplinary communications, as well as the development of ecological thinking and worldviews of pupils, about the development of content, forms, teaching methods, ways of their development, environmental protection and interdisciplinary communication, are developed in synchronous and asynchronous teaching of biology in connection with natural subjects.

KEYWORDS:- Interdisciplinary integration, natural subjects, ecological thinking, knowledge, improvement, pupils, form, method, means, ecological culture, skill, qualification, environment, man and nature.

\section{INTRODUCTION}

Consequently, integrated education provides a new approach to the content of science - based knowledge in schools, and its main goal is to form a holistic scientific view of the world and society in the minds of pupils, to form a scientific understanding of nature and the role of man in it and it consists of the compilation of scientific insights and knowledge about the role of man.

Knowledge of the surrounding nature has an influence on the comprehensive development and upbringing of pupils. Through the study of this knowledge, pupils try to identify the factors that cause environmental problems by analyzing the relationship between nature and man, the nature of their interconnectedness and unity, their relationship to the environment, the behavior of nature conservation. This action creates the basis for the formation of interdisciplinary knowledge and concepts in pupils.

This opportunity is suplied on the basis of an interdisciplinary approach. It can be seen both as a form of integration of academic disciplines and as a method of synthesizing subjective new knowledge. The interdisciplinary approach is considered to be the most optimal direction for the science of biology in the integration of general education and natural sciences. The result of the integration of academic disciplines is based on the conceptual idea that the acquisition of new subjective knowledge that 
CURRENT RESEARCH JOURNAL OF PEDAGOGICS 2(10): 12-16, October

2021 DOI: https://doi.org/10.37547/pedagogics-crjp-02-10-03

ISSN 2767-3278

(C)2021 Master Journals

\section{Crossref dof 81 Google}

Accepted 08th October, 2021 \& Published $13^{\text {th }}$ October, 2021

cannot be formed when disciplines are taught without interconnection [2].

In particular, it is one of the leading natural sciences - biology has a very responsible role in shaping the scientific outlook of pupils. Therefore, the content of both school biology curriculum has great potential in shaping the scientific worldview in pupils. In teaching biology, first of all, it is necessary to acquaint pupils with the basic concepts, ideas, theories, laws of biology, their role in various sectors of the economy, the importance of biological knowledge, to use pupils' knowledge of chemistry and physics in problematic situations. An educational system is created, which is inextricably linked with the formation of ecological thinking in pupils and the formation of a conscious attitude of man to nature and society 10].

This system combines the issues of formation of scientific outlook and ecological thinking, spiritual, moral, patriotic, ecological, aesthetic, economic, physical, hygienic, labor and international education of pupils, as well as the solid mastering of the basics of science by pupils.

In the interdisciplinary teaching of biology, the principles of selection of materials on the content of improving pupils' knowledge of the ecological content were required. In this case, mainly in the interdisciplinary teaching of biology, the interaction of materials in the context of the development of ecological thinking in pupils is considered. This can be done on the basis of didactic principles.

So, based on didactic principles, to ensure interdisciplinary relevance in addition to the curriculum materials in biology; it is possible to add the required amount to each training material. Its structure and effectiveness in training; the relevance of theoretical teaching materials to practice; it is necessary to take into account and analyze the extent to which pupils are able to master the materials provided by them, taking into account their age characteristics, and to illuminate the essence of the concepts related to the formation of ecological thinking.

Integrated education primarily involves the convergence, integration, and integrated teaching of disciplines that are close and compatible with each other. The integration of educational content is of great importance for both the teacher and the pupil, is one of the important factors in improving the quality of education, improving the activities of pupils, activating, strengthening their knowledge, stimulating them and self-development [7].

The implementation of ecological knowledge in the interdisciplinary teaching of natural sciences in the educational process should be considered as a natural process of their development and a factor in the development of pupils' scientific outlook and thinking.

According to M.T.Gafurov's research work, he proposes the issue of strengthening ecological knowledge by integrating the process of teaching related sciences on the basis of ecological goals and directing them to a single, mutually beneficial goal [3].

A.Y. Danilyuk states that the concept of integration is introduced in the context of pedagogy, but the pedagogical supplement, which is not sufficiently meaningful, does not provide to speak about it as a sufficiently wellfounded scientific and pedagogical concept [4].

"Environmental Education in Biology Subject" by M. Nishonboeva's textbook focuses on interdisciplinary links in biology lessons, the use of physical concepts and laws in the teaching of biology, the formation of biophysical concepts in pupils, the conscious and deep mastery of knowledge in natural sciences. It consists of an integrated system of scientific knowledge about 
CURRENT RESEARCH JOURNAL OF PEDAGOGICS 2(10): 12-16, October

2021 DOI: https://doi.org/10.37547/pedagogics-crjp-02-10-03

ISSN 2767-3278

(C)2021 Master Journals

Crossref di) 81 Google

Accepted 08th October, 2021 \& Published $13^{\text {th }}$ October, 2021

nature and society, their interdependence, the laws of nature. It was noted that it is expedient to use environmental issues in the organization of lessons based on the interaction of biology, chemistry and physics [9].

In the research work of E.O. Turdikulov claimed the problem of integrated teaching of natural sciences, which is considered to form a whole about the universe, the integration of education is a high level of interdisciplinary connection, a tool that allows to create a whole integrated knowledge [12].

R.H. Djuraev's research work states on one of the most important problems of education, namely the integration and stratification of knowledge. In particular, according to the scientist, integration serves to establish structural connections between different systems of knowledge, to generalize them, to form a holistic view of pupils about nature and society.

So the history of human development, all cases of conscious attitude towards nature or harm to it have been regulated by spiritual-moral norms. At the intersection of the interests of nature, man and technology, a person's level of education and upbringing is measured by moral and spiritual maturity and thinking [6].

Ecological culture is constantly learned to secondary school pupils in the natural sciences, as well as through extracurricular and out-ofschool educational activities, biological knowledge of the environment, plants and animals is instilled in children in the context of interdisciplinary connections.

It is known that the subject "Biology" is the main subject of teaching the basics of ecology. These disciplines play an important role in the formation of ecological knowledge, ecological thinking and ecological culture. It is necessary to acquaint pupils with nature, to keep abreast of various environmental events.

Scientist I.D.Zverev claims that in order to be ecologically cultured, everyone must first acquire ecological knowledge, then - moral values in relation to nature, and finally - practical skills and abilities to protect and improve the environment. According to the scientist, the prevention or elimination of negative impacts on nature is a key indicator of environmental culture [5].

According to L.A. Mukhtarova, environmental problems have become a global problem. Therefore, the solution to this problem is not one or two states, but many countries that care about the balance of the world around us. The current environmental crisis in various parts of the globe means that we need to treat nature properly and pay more attention to it. In particular, the solution of this problem has risen to the level of state policy in our country [8].

The integrity of pupils' worldview, the interdependence of objects and events in the objective world means the interdependence of nature, society, technology, man through interdisciplinary interdependence in this educational process.

In the interdisciplinary teaching of biology, the following tasks should be performed in the formation of ecological knowledge in pupils:

1. Acquisition by pupils of scientific knowledge about the integrity of nature, the relationship between society and nature, the acquisition of environmental knowledge, skills and competencies that form the basis for the formation of a conscious attitude towards nature.

2. To explain the broader significance of nature and its components, and to distinguish between renewable and nonrenewable resources.

3. Measures taken for the economical use of 
natural resources, protection of the environment, landscaping and reproduction of natural resources, the formation of motives for active participation in socially useful work.

The conditions for the logical development of the curriculum in the interrelated are:

- to establish the connection between the objects considered in different educational disciplines;

- to establish the connection between related laws and theories;

- to organize of the relationship between psychological, pedagogical and philosophical knowledge, as well as methodological methods and techniques of education.

The possibilities of integrating general education, as well as special categories of sciences, are embodied in their content, which expresses knowledge about the environment, which is unique in nature.

Today, it has become a requirement of the time for pupils not only to have in - depth knowledge, but also to develop their professional skills through the acquisition of skills.

One of the important factors of the effectiveness of education is the effective organization of educational activities, the correct use of various methods, techniques, tools in the classroom, their application in an integrated manner. This is done through integrated learning [1].

The following should be given into account when teaching through the integration of disciplines:

- $\quad$ each lesson should be goal-oriented;

- the selected additional material on interdisciplinary connection must be connected with the subject;

- $\quad$ it is possible to identify ways to work with pupils in order to increase their activity;
- the lesson should be not only educational, but also aimed at educating pupils in the humanities;

- based on the content of the topic, scientific knowledge about nature, society, human thinking, development, should be aimed at forming confidence and faith in the future of our country.

Such technology teaches pupils to imagine the world differently, not to memorize the theoretical rules of connecting practice with life, to understand the harmony of the individual and society, to achieve diversity of opinion, nonstandard thinking, as well as to understand ways of self-development.

The advantages of the integrated course are:

1. In this type of activity, the child begins to imagine the world as a whole.

2. The child's potential develops, he begins to study the environment with great interest, the events begin to search for a logical reason in the mind. As a result, the ability to communicate, compare, generalize, and draw conclusions develops.

Integrated lessons teach children to understand the nature of the whole worldview, the coherence of events. The science of technology can be inextricably linked with the subjects studied at school, and the educational and creative nature of labor is realized through the use of scientific knowledge.

Integration serves to unite all the components of the educational process (content, form, methods and tools) into a single system. In addition, it is an important factor in ensuring the quality and effectiveness of education [11].

The intellectual development of the pupil's personality, in-depth, specialized teaching, increasing their scientific thinking and intellectual potential is a topical issue today. 
CURRENT RESEARCH JOURNAL OF PEDAGOGICS 2(10): 12-16, October

2021 DOI: https://doi.org/10.37547/pedagogics-crjp-02-10-03

ISSN 2767-3278

(C)2021 Master Journals

Crossref do: 81 Google

Accepted 08 ${ }^{\text {th }}$ October, 2021 \& Published $13^{\text {th }}$ October, 2021

In order to identify unexplored aspects of interdisciplinary links in the educational process, the research work of a number of pedagogical scientists on this issue was studied in detail. It consists of the study of unexplored aspects of interdisciplinary relations on the basis of approaches that do not contradict the theoretically recognized laws.

\section{REFERENCES}

1. Якибова Д. Методы развития творческого мышления младших школьников //Вестник педагогики. Науки и практика. - 2021. - Т. 1. - №. 1.

2. Нарбутаев Х.Б. Повышение экологической культуры студента при преподавании биологии в связи с другими дисциплинами.// Теоретические и прикладные науки. - С. 714-717.- №.6.

3. Гафуров М.Т. Формирование эколого экономических знаний учащихся процессе извучения естественно-географических дисциплин. Автореф. дис. ... канд. пед. наук. - Йошкар - Ола, 2012. - 24 с.

4. Данилюк, А. Я. Учебный предмет как интегрированная система / А.Я.Данилюк // Педагогика. - 1997. - № 4. - С. 24 - 28.

5. Зверев И.Д. Экология в школьном образовании. -М.: Знание, 1988. - $96 \mathrm{c}$.

6. Исақулова Н.Ж. Ўқувчиларга экологик тарбия бериш назарияси ва амалиёти. Монография. -Т.: Фан, 2011. -140 б.

7. Mavlonova R.A., Rahmonqulova N.H. Boshlang'ich ta'limning integrasiyalashgan pedagogikasi. O'quv qo'llanma. - Toshkent. Ilm Ziyo.- 2009.-192 b.
8. Мухтарова Л.А. The methods of formation of the culture of ecologic security in students in the teaching of natural sciences. International Engineering Journal For Research \& Development Vol.5 Issue 4 EISSN NO:-2349 - 0721. 2020 - P. 1-5

9. Нишонбоева М.Г. Биология дарсларида экологик тарбия. Тошкент. Ўқитувчи, 1992. -104 б.

10. Norbutayev Kh.B. The $f$ ormation of ecological thought of pupils in teaching of biology in connection with natural sciences in the process of the lesson. European Journal of Research and Reflection in Educational Sciences, 8 (3) Part II, 2020. - P. 134-138.

11. Раченко И.П. Интегрированная педагогика. Част 1. Пятигорск: Изд. Пятигорского государственного лингвистического университета, 1997. - C.212.

12. Турдикулов Э.А. Экологические образование и воспитание учашихся. Ташкент. Ўкитувчи, 1991. -192 с.

13. Shomirzayev, M. K. (2020). The concept of pedagogical technology and basic principles. ACADEMICIA: An International Multidisciplinary Research Journal, 10(11), 1551-1560.

14. Shomirzayev, M. K. (2021). Practical lessons in technology: Characteristics of organization and conduct. ASIAN JOURNAL OF MULTIDIMENSIONAL RESEARCH, 10(4), 991-1001. 